\title{
Laser Cleaning of Contaminated Painted Surfaces
}

\author{
Semi-Annual Report \\ November 1, 1996 - March 31, 1997
}

\author{
By: \\ Ames A. Grisanti \\ Robert R. Jensen
}

Work Performed Under Contract No.: DE-FC21-94MC31388

For

U.S. Department of Energy

Office of Environmental Management

Office of Technology Development

1000 Independence Avenue

Washington, DC 20585
U.S. Department of Energy

Office of Fossil Energy

Federal Energy Technology Center Morgantown Site

P.O. Box 880

Morgantown, West Virginia 26507-0880
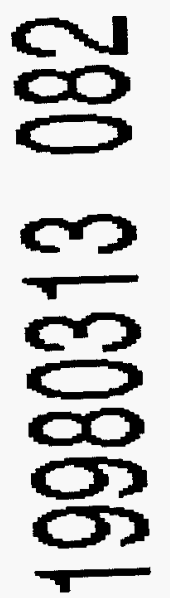

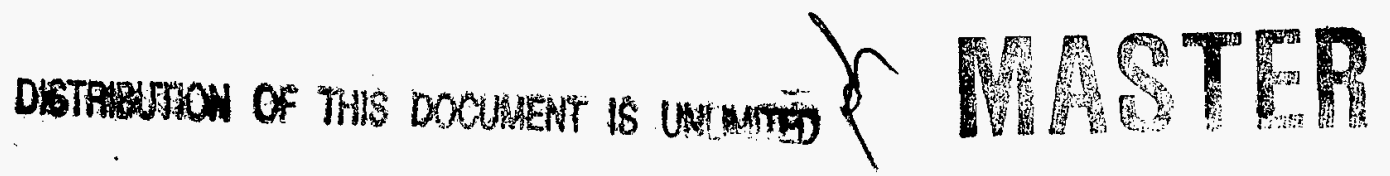

By

Energy \& Environmental Research Center

University Of North Dakota

P.O. Box 9018

Grand Forks, North Dakota 58202-9018 


\section{Disclaimer}

This report was prepared as an account of work sponsored by an agency of the United States Government. Neither the United States Government nor any agency thereof, nor any of their employees, makes any warranty, express or implied, or assumes any legal liability or responsibility for the accuracy, completeness, or usefulness of any information, apparatus, product, or process disclosed, or represents that its use would not infringe privately owned rights. Reference herein to any specific commercial product, process, or service by trade name, trademark, manufacturer, or otherwise does not necessarily constitute or imply its endorsement, recommendation, or favoring by the United States Government or any agency thereof. The views and opinions of authors expressed herein do not necessarily state or reflect those of the United States Government or any agency thereof. 


\section{DISCLAIMER}

This report was prepared as an account of work sponsored by an agency of the United States Government. Neither the United States Government, nor any agency thereof, nor any of their employees makes any warranty, express or implied, or assumes any legal liability or responsibility for the accuracy, completeness, or usefulness of any information, apparatus, product, or process disclosed or represents that its use would not infringe privately owned rights. Reference herein to any specific commercial product, process, or service by trade name, trademark, manufacturer, or otherwise does not necessarily constitute or imply its endorsement, recommendation, or favoring by the United States Government or any agency thereof. The views and opinions of authors expressed herein do not necessarily state or reflect those of the United States Government or any agency thereof.

\section{EERC DISCLAIMER}

LEGAL NOTICE This research report was prepared by the Energy \& Environmental Research Center (EERC), an agency of the University of North Dakota, as an account of work sponsored by U.S. Department of Energy Federal Energy Technology Center. Because of the research nature of the work performed, neither the EERC nor any of its employees makes any warranty, express or implied, or assumes any legal liability or responsibility for the accuracy, completeness, or usefulness of any information, apparatus, product, or process disclosed, or represents that its use would not infringe privately owned rights. Reference herein to any specific commercial product, process, or service by trade, trademark, manufacturer, or otherwise does not necessarily constitute or imply its endorsement or recommendation by the EERC.

\section{ACKNOWLEDGMENT}

This semiannual report was prepared with the support of the U.S. Department of Energy (DOE), Federal Energy Technology Center, Cooperative Agreement No. DE-FC21-94MC31388. However, any opinions, findings, conclusions, or recommendations expressed herein are those of the author(s) and do not necessarily reflect the views of the DOE. 


\section{TABLE OF CONTENTS}

LIST OF FIGURES $\ldots \ldots \ldots \ldots \ldots \ldots \ldots \ldots \ldots \ldots \ldots \ldots \ldots \ldots \ldots$

INTRODUCTION $\ldots \ldots \ldots \ldots \ldots \ldots \ldots \ldots \ldots \ldots \ldots \ldots \ldots \ldots \ldots \ldots \ldots \ldots$

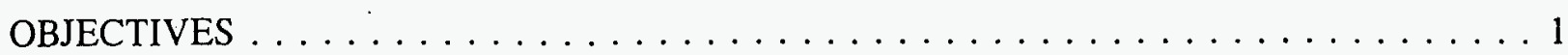

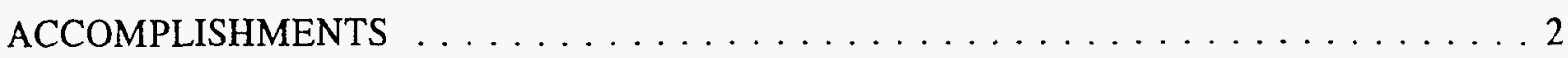

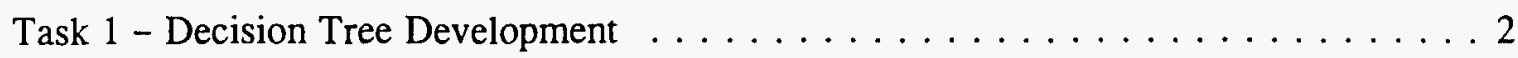

Task 2 - Literature Search for Surface Decontamination Reports . . . . . . . . . . 2

Task 3 - Compilation of Database from Literature Data . . . . . . . . . . . 2

FUTURE WORK $\ldots \ldots \ldots \ldots \ldots \ldots \ldots \ldots \ldots \ldots \ldots \ldots \ldots \ldots \ldots \ldots \ldots \ldots$

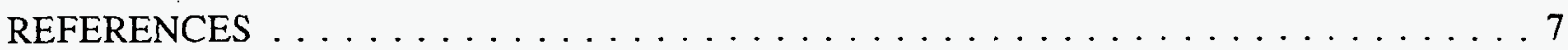

LITERATURE DATABASE $\ldots \ldots \ldots \ldots \ldots \ldots \ldots \ldots \ldots \ldots \ldots \ldots \ldots \ldots$ Appendix A

\section{LIST OF FIGURES}

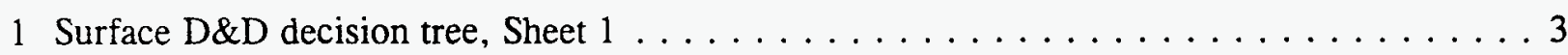

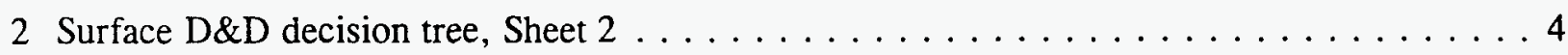

3 Surface D\&D decision tree, transportation costs $\ldots \ldots \ldots \ldots \ldots \ldots \ldots \ldots \ldots$

4 Production rate and end point achieved for painted steel plate $\ldots \ldots \ldots \ldots \ldots$

5 Production rate and end point achieved for painted steel I-beam $\ldots \ldots \ldots \ldots \ldots \ldots$

6 Figure of merit for various surface decontamination techniques applied to painted plate and I-beam . . . . . . . . . . . . . . . . . . . . 7 


\section{LASER CLEANING OF CONTAMINATED PAINTED SURFACES}

\section{INTRODUCTION}

Surface decontamination of concrete and steel surfaces in nuclear facilities provides cost savings during decommissioning operations by allowing recycling or reuse of concrete and steel structures. Separation of radionuclides and other contamination from the concrete or steel substrates also allows reduction in the volume of hazardous materials during the decontamination and decommissioning (D\&D) process, resulting in further cost savings.

Several techniques are available or under development for surface decontamination in nuclear facilities. Each technique has its merits; however, none of them is universally the best choice for all surface decontamination applications. The following are some issues which confront an organization selecting a surface decontamination technique for a particular application:

- Project scale

- Concrete or metal surfaces

- Contamination by radiological and other hazardous materials

- Stage of surface decontamination technology development (e.g., commercial, research and development [R\&D])

- Equipment operating costs

- Collection of waste generated by surface decontamination

- Occupational health and safety requirements

- Utilities required for operations

- Real-time control of surface decontamination

- Recycling or reuse of decontaminated substrates

- Waste

- Characterization

- Classification

- Transport

- Storage

- Treatment

- Disposal

- D\&D equipment decontamination

Because of the multitude of factors which influence the environmental and economic aspects of selecting a surface decontamination technique, it is difficult to select the best method in a given situation. An objective basis for comparing techniques is needed.

\section{OBJECTIVES}

The objective of this project is to develop a software tool for use by personnel who must select a surface decontamination technique. The software will incorporate performance data for available surface decontamination techniques. 
The major activities in the project are broken down as follows:

Task 1 - Complete decision tree development

Task 2 - Literature search for surface decontamination reports

Task 3 - Compilation of database from literature data

Task 4 - Sensitivity analysis and model design

Task 5 - Design of model data structures

Task 6 - PC software design and coding

\section{ACCOMPLISHMENTS}

\section{Task 1 - Decision Tree Development}

A decision tree has been developed which gives the underlying structure for evaluating available surface decontamination techniques for a particular situation. The overall process of surface decontamination is evaluated for a given technology as depicted in Figures 1 and 2. Some of the boxes depicted in Figures 1 and 2 represent flowcharts within themselves, such as those involving waste classification, storage, transport, and treatment. Therefore, flowcharts detailing these areas also have been developed. A flowchart giving details of waste transport costs has been developed and is shown in Figure 3. The flowchart of Figure 3 has been developed using recently available data (1) and allows classification of the transportation mode needed for waste, based on waste type and volume.

\section{Task 2 - Literature Search for Surface Decontamination Reports}

A database of available literature on or relating to surface decontamination operations has been completed. All literature in the database is on file in hard copy or microfiche. Initial review of all articles was done to determine the articles which have the most pertinent information for surface decontamination systems analysis. Detailed review and compilation of information from articles is complete. A listing of the literature database is provided in Appendix A.

\section{Task 3 - Compilation of Database from Literature Data}

Data on surface decontamination operations are being gleaned from available reports. Several articles (2-9) contain evaluations of surface decontamination techniques for specific cases. Data have been compiled from a number of articles, and an attempt has been made to put the data into a form that will allow comparison. A preliminary analysis of data is presented below.

Figures 4 and 5 show a comparison of production rate and end point achieved for various surface decontamination techniques on painted steel plate and I-beam. The graphs in Figures 4 and 5 have been normalized to the maximum value to allow comparison of production rate and end point. The data in Figures $4-6$ have been compiled from work done at Florida International University (3).

Figure 6 shows a comparison of techniques based on a calculated figure of merit. The figure of merit is a normalized sum based on the techniques performance in the areas of capital 


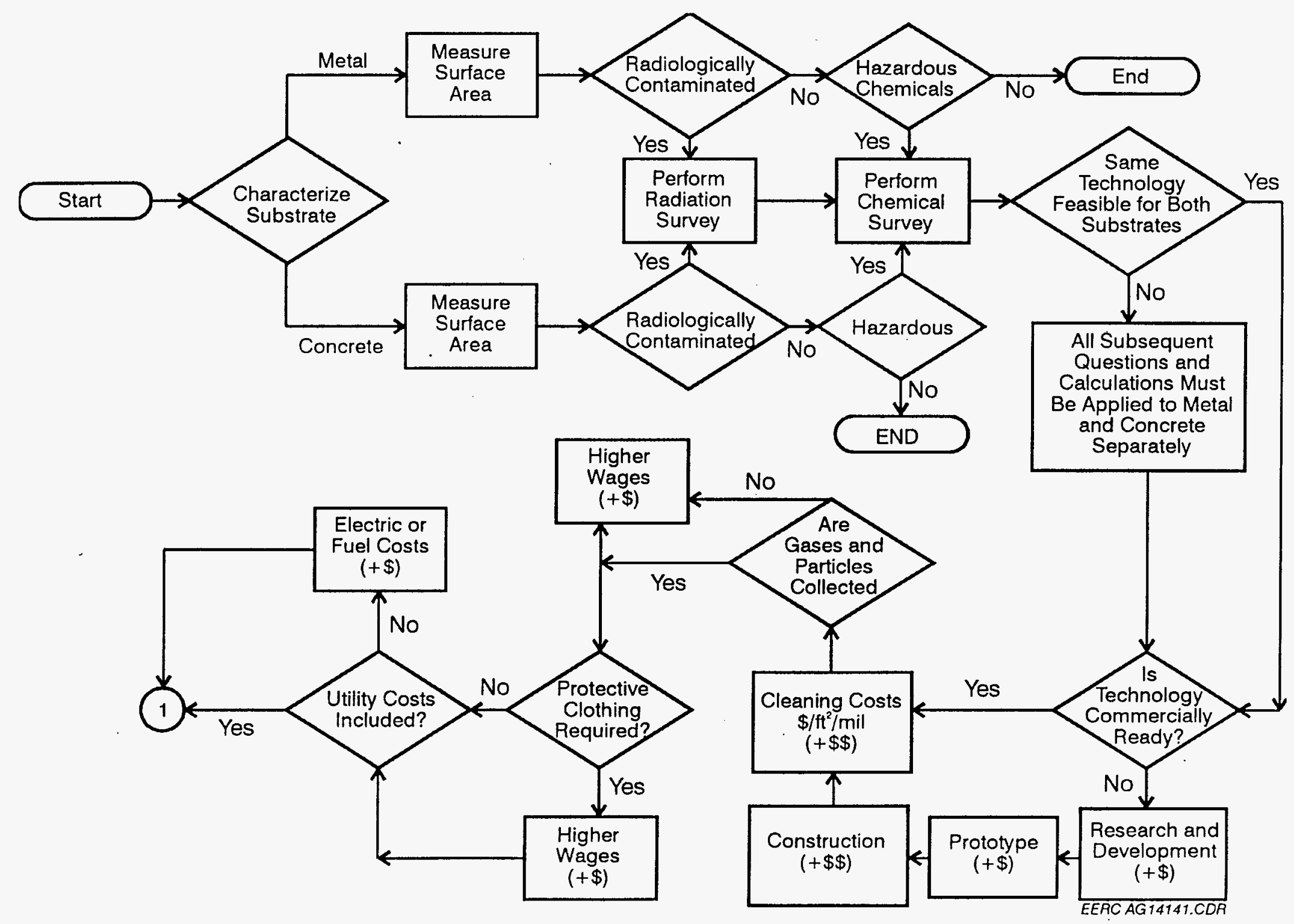

Figure 1. Surface D\&D decision tree, Sheet 1. 


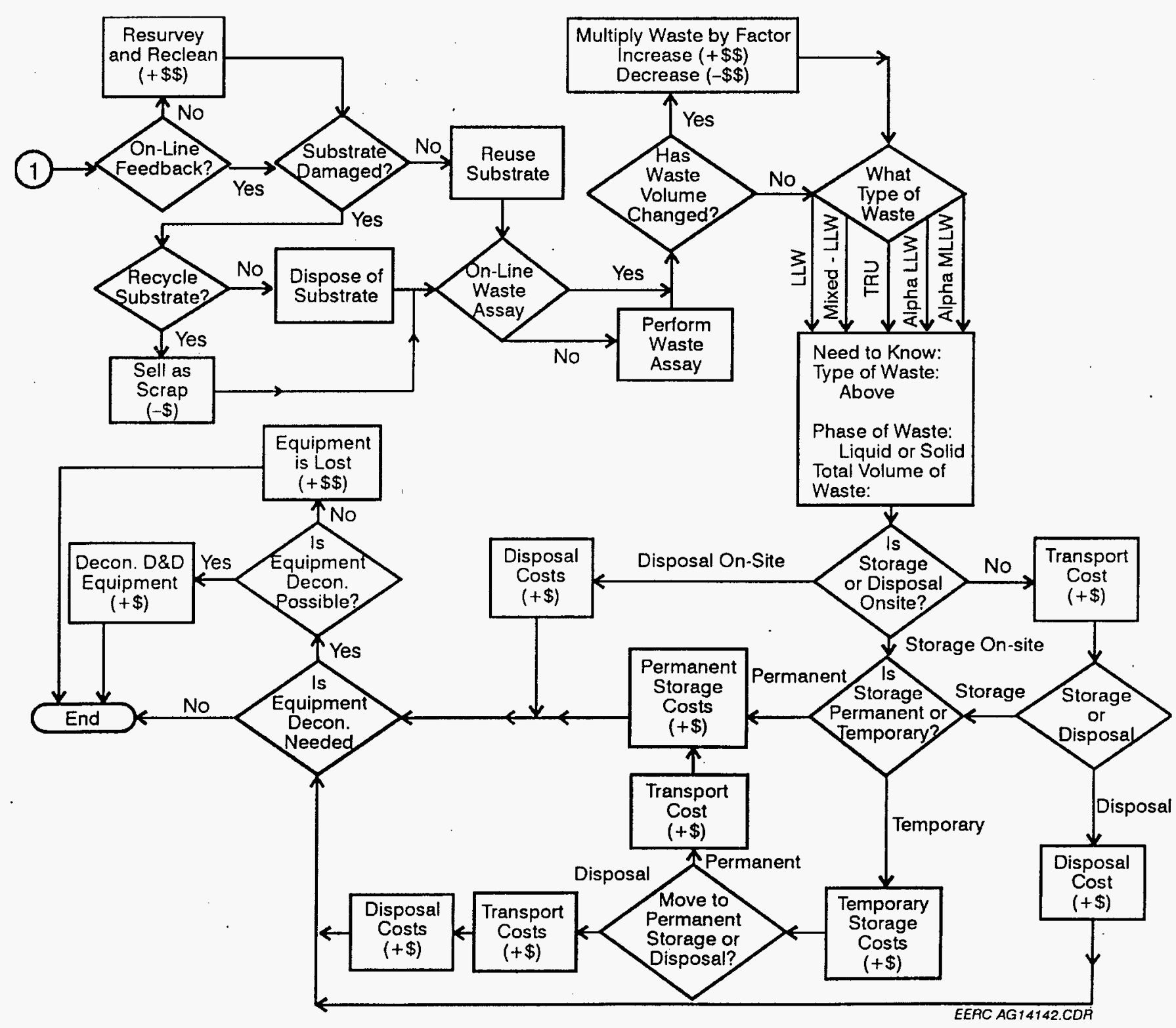

Figure 2. Surface D\&D decision tree, Sheet 2. 


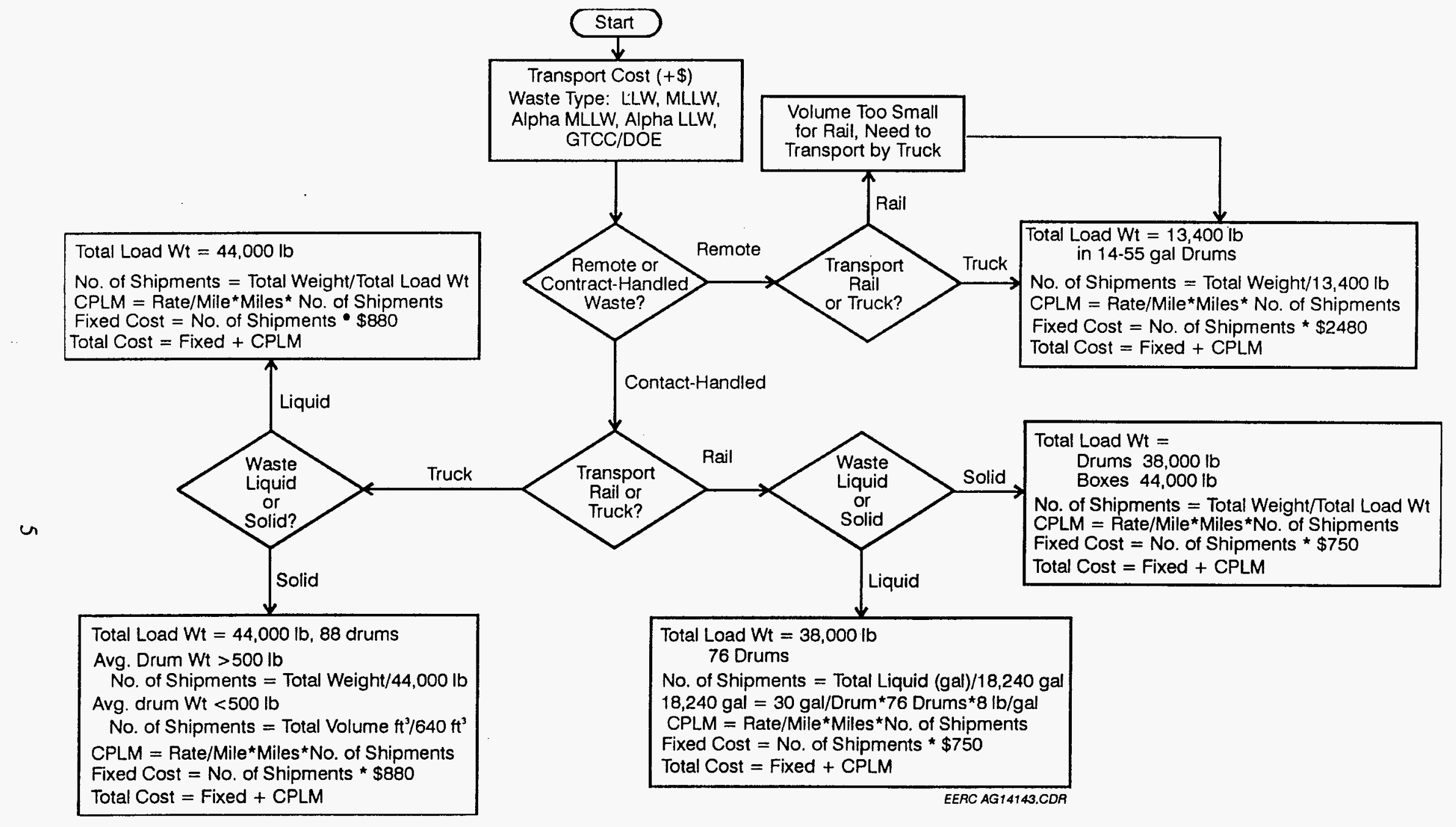

Figure 3. Surface D\&D decision tree, transportation costs. 


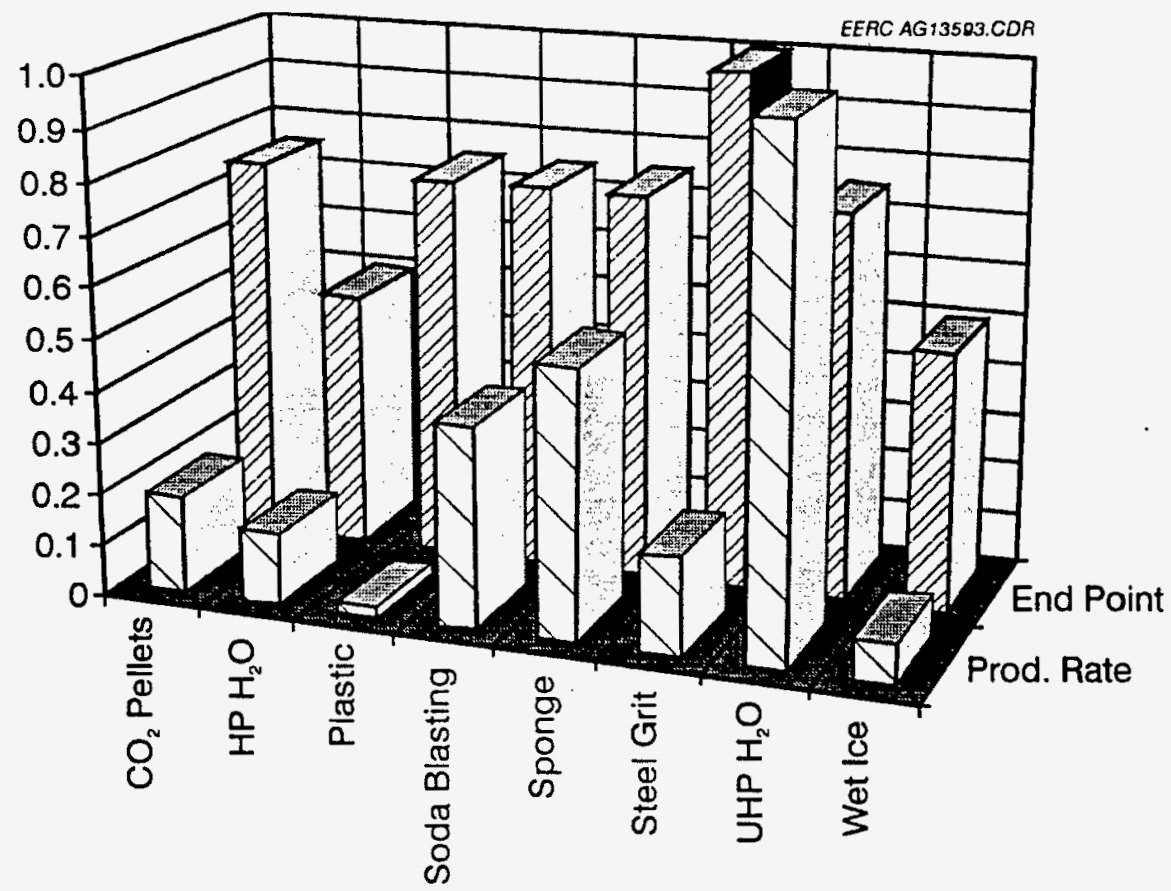

Figure 4. Production rate and end point achieved for painted steel plate.

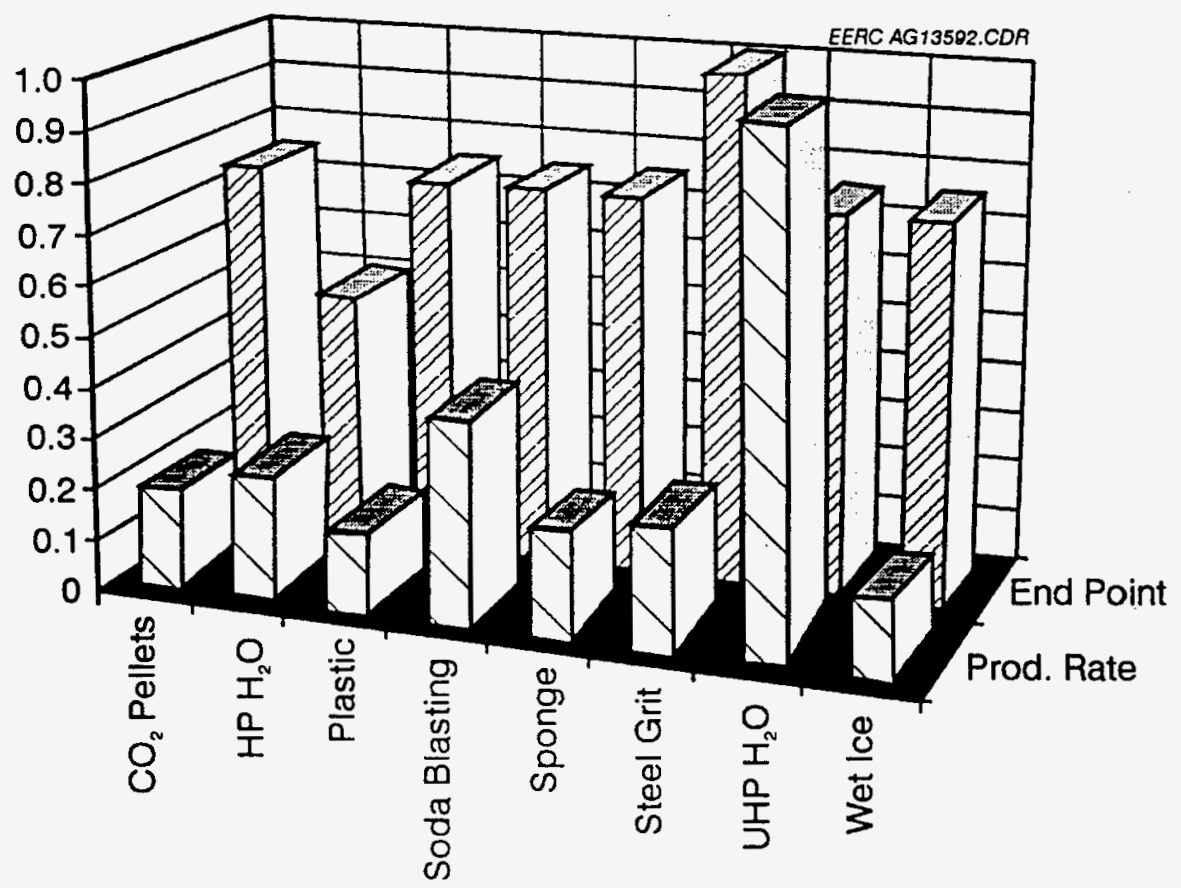

Figure 5. Production rate and end point achieved for painted steel I-beam. 


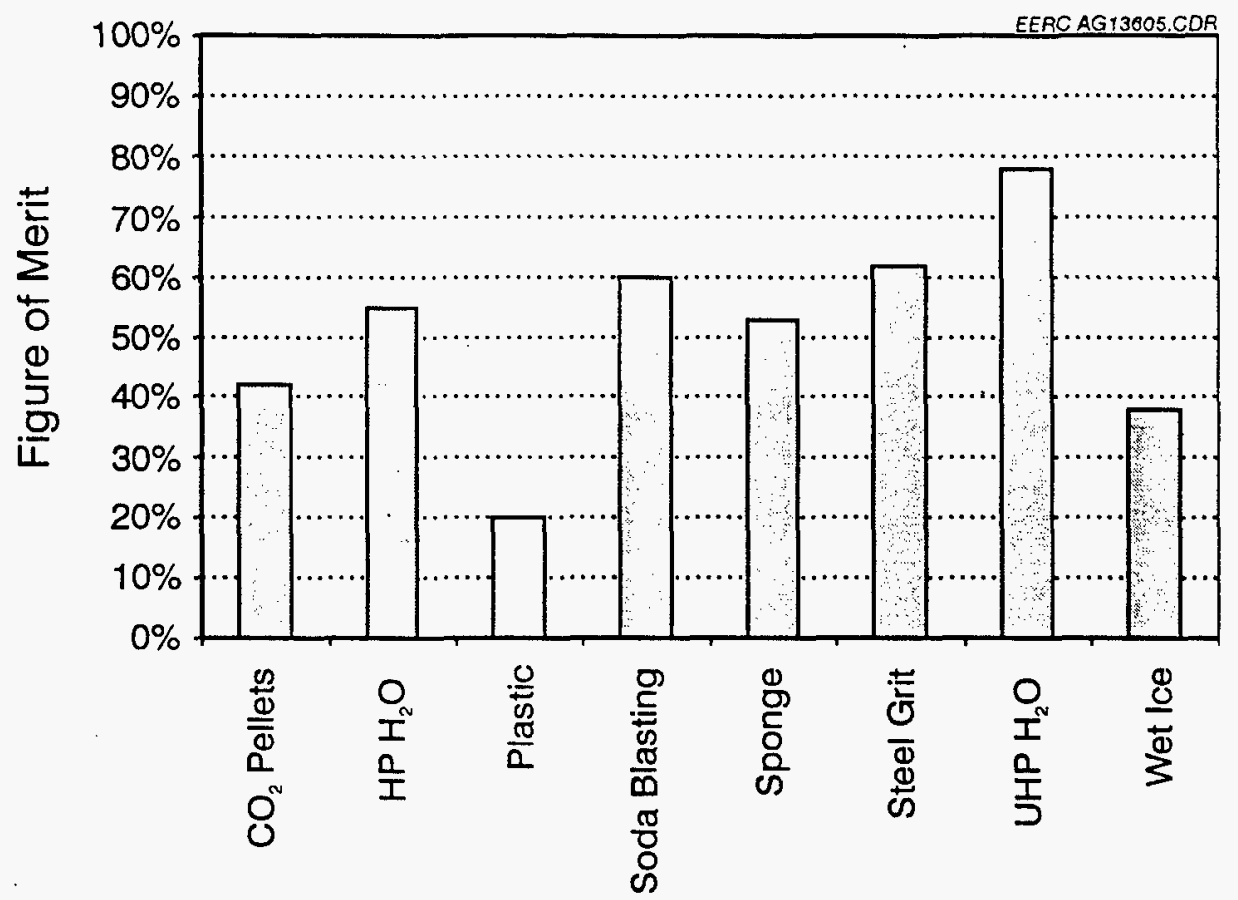

Figure 6. Figure of merit for various surface decontamination techniques applied to painted plate and I-beam.

cost, operating cost, production rate (plate and I-beam), and end point (plate and I-beam). The data in Figure 6 do not take into consideration any aspects of waste disposal.

\section{FUTURE WORK}

Completion of the decision tree and compilation of literature data will take place in the next quarter. Activities relating to software design and coding and sensitivity analysis will be initiated during the next quarter.

\section{REFERENCES}

1. Feizollahi, F.; Shropshire, D.; Burton, D. "Waste Management Facilities Cost Information for Transportation of Radioactive and Hazardous Materials," U.S. Department of Energy, DE96002295, 1995, pp 1-21.

2. Archibald, K.E. "Concrete Decontamination Scoping Tests," U.S. Department of Energy Idaho National Engineering Laboratory, Idaho Falls, ID, 1995, pp 1-19.

3. Ebadian, M.A.; Lagos, L.E.; Boudreaux, J.F.; Clark, T.R.; Miller, L.K. "Analysis of Potential Surface Blasting Decontamination Technologies for Structural Steel," Fernald Environmental Restoration Management Corporation, Cincinnati, OH, 1995, pp 1-41. 
4. Grieco, S.A.; Neubauer, E.D.; Rhea, J.R. "Removal and Treatment of Radioactive, Organochlorine, and Heavy Metal Contaminants from Solid Surfaces/Radioactive and Hazardous Surface Decontamination Utilizing Soda Blasting," U.S. Department of Energy, New York, NY, 1995, pp 1-10.

5. White, T.L.; Foster, D. Jr.; Wilson, C.T.; Schaich, C.R. "Phase 2 Microwave Concrete Decontamination Results," Waste Management '95: Working Towards a Cleaner Environment, U.S. Department of Energy, Oak Ridge, TN, DE95010212CT, 1995.

6. Corleto, P.; Guidotti, M.; Ragazzo, G. "A Microwave System to Scarify Concrete Surfaces Upgrading and Testing," Proceedings of the International Topical Meeting on Nuclear and Hazardous Waste Management Spectrum '94; American Nuclear Society, Inc.: LaGrange Park, IL, 1994, pp 369-373.

7. Halter, J.M.; Sullivan, R.G. "Techniques for Removing Contaminated Concrete Surfaces," Environmental Decontamination 1979, 185-194.

8. Halter, J,M.; Sullivan, R.G. "Contaminated Concrete Surface Layer Removal," EY-76-C-061830; reprinted from Surface Contamination, Vol. 1; Mittal, K.L., Ed.; Plenum Publishing: New York, 1979, pp 443-455.

9. Barbier, M.M.; Chester, C.V. "Decontamination of Large Horizontal Concrete Surfaces Outdoors," U.S. Department of Energy, W-7405-eng-26, pp 1-26. 
APPENDIX A

\section{LITERATURE DATABASE}


1. U.S. Department of Energy. "Technology Assessment: Laser Technologies for Decontamination and Decommissioning of Nuclear Facilities," Decontamination and Decommissioning Focus Area, Morgantown Energy Technology Center, 1996, pp 1-16.

2. Darnell, G.R.; Larsen, M.M. "Existing LLW Treatment and Disposal Technology Offers 17to-1 Volume Reduction and Advanced Disposal at Low Cost," U.S. Department Energy Idaho National Engineering Laboratory, Idaho Falls, ID, DE-AC07-761D01570, 1996, pp 15-21.

3. Goodwill, M.E.; Lively, J.W.; Morris, R.L. "Radiological Decontamination, Survey, and Statistical Release Method for Vehicles," U.S. Department of Energy, Grand Junction, CO, DE-AC04-86ID12584, 1996, pp 1-12.

4. Kaelin, A.B. "Properly Engineer Lead Paint Removal Projects," Chemical Engineering Progress 1996, 50-55.

5. Archibald, K.E. "Concrete Decontamination Scoping Tests," U.S. Department of Energy Idaho National Engineering Laboratory, Idaho Falls, ID, 1995, pp 1-19.

6. Benson, C.E.; Parfitt, J.E.; Patton, B.D. "Decontamination of Surfaces by Blasting with Crystals of $\mathrm{H}_{2} \mathrm{O}$ and $\mathrm{CO}_{2}$," U.S. Department of Energy, Oak Ridge, TN, DE-AC05$840 R 21400,1995$, pp 1-63.

7. Bierschbach, M.C. "Estimating Pressurized Water Reactor Decommissioning Costs," Pacific Northwest Laboratory, Richland, WA, NUREG/CR-6054, 1995, pp 1-150.

8. Boudreaux, J.F. "Comparative Analysis of Surface Decontamination Technologies for Standard Steel Shapes," Abstracts, U.S. Department of Energy Office of Environmental Restoration, 1995 , p 75.

9. Ebadian, M.A.; Lagos, L.E.; Boudreaux, J.F.; Clark, T.R.; Miller, L.K. "Analysis of Potential Surface Blasting Decontamination Technologies for Structural Steel," Fernald Environmental Restoration Management Corporation, Cincinnati, OH, 1995, pp 1-41.

10 Feizollahi, F.; Shropshire, D.; Burton, D. "Waste Management Facilities Cost Information for Transportation of Radioactive and Hazardous Materials," U.S. Department of Energy Idaho National Engineering Laboratory, Idaho Falls, ID, DE96002295, 1995, pp 1-21.

11. Grieco, S.A.; Neubauer, E.D.; Rhea, J.R. "Removal and Treatment of Radioactive, Organochlorine, and Heavy Metal Contaminants from Solid Surfaces/Radioactive and Hazardous Surface Decontamination Utilizing Soda Blasting," U.S. Department of Energy, New York, NY, 1995, pp 1-10.

12. Grieco, S.A.; Neubauer, E.D.; Rhea, J.R. "Radioactive and Hazardous Surface Decontamination Utilizing Soda Blasting/Removal and Treatment of Radioactive Contaminants/Removal and Treatment of Radioactive, Organochlorine, and Heavy Metal Contaminants from Solid Surfaces/Soda Blasting Decontamination Process," The O'Brien \& Gere Companies, 1995, pp 1-9. 
13. Hanulik, J. "Process for Decontaminating Radioactive Metal Surfaces," CAX Nos. 5386078, 4882503, 4508641, 4587043, 5008044, and 5024805, 1995.

14. Krupa, B. "Evaluation of Plant 7 Decontamination Methods," Abstracts, 1995, p 21.

15. Moore, T. "Rising to the Challenge in Military-Site Cleanups," Environ. Eng. World 1995, 28-33.

16. Reisch, M.S. "Paints and Coatings," C\&EN 1995, 30-31.

17. Shropshire, D.; Feizollahi, F. "Life Cycle Cost Estimation and Systems Analysis of Waste Management Facilities," U.S. Department of Energy Idaho National Engineering Laboratory, Idaho Falls, ID, DE96001615, 1995, p 12.

18. Trovato, S.A.; Parry, J.O.; Monti, W.A.; Burger, J.M. "Decontaminating a Nuclear Power Plant," Mechanical Engineering 1995, 76-78.

19. White, T.L.; Foster, D., Jr.; Wilson, C.T.; Schaich, C.R. "Phase 2 Microwave Concrete Decontamination Results," Waste Management '95: Working Towards a Cleaner Environment, U.S. Department of Energy, Oak Ridge, TN, DE95010212CT, 1995.

20. "Escalation of Decommissioning Waste Disposal Costs at Low-Level Waste Burial Facilities," report on waste burial charges, U.S. Nuclear Regulatory Commission, Washington, DC, NUREG-1307, 1994, pp 1.1-4.1.

21. "Escalation of Decommissioning Waste Disposal Costs at Low-Level Waste Burial Facilities," report on waste burial charges, Division of Regulatory Applications, Washington, DC, NUREG-1307, 1994.

22. Bonem, M.W. "Economical Decontamination of Concrete and Metal Using the TechXtract Process," Proceedings of the International Topical Meeting on Nuclear and Hazardous Waste Management Spectrum '94; American Nuclear Society, Inc.: LaGrange Park, IL, 1994, pp 2434-2438.

23. Corleto, P.; Guidotti, M.; Ragazzo, G. "A Microwave System to Scarify Concrete Surfaces Upgrading and Testing," Proceedings of the International Topical Meeting on Nuclear and Hazardous Waste Management Spectrum '94; American Nuclear Society, Inc.: LaGrange Park, IL, 1994, pp 369-373.

24. Demmer, R. "Testing and Evaluation of Eight Decontamination Chemicals," U.S. Department of Energy Westinghouse Idaho Nuclear Company, Inc., Idaho Falls, ID, 1994, pp 1-13.

25. Demmer, R.L.; Ferguson, R.L. "Testing and Evaluation of Light Ablation Decontamination," U.S. Department of Energy Idaho National Engineering Laboratory, Idaho Fall, ID, 1994, pp 1-27. 
26. Demmer, R.L. "Development of Simulated Contamination (SIMCON) and Miscellaneous Decontamination Scoping Tests," U.S. Department of Energy Westinghouse Idaho Nuclear Company, Inc., Idaho Falls, ID, DEAC07841D 12435, 1994, pp 1-13.

27. Feizollahi, F.; Shropshire, D.; Burton, D. "Waste Management Facilities Cost Information for Transportation of Radioactive and Hazardous Materials. Revision 1," U.S. Department of Energy, San Francisco, CA, DE95002022, 1994, 203 p.

28. Feizollahi, F.; Shropshire, D. "Interim Report: Waste Management Facilities Cost Information for Mixed Low-Level Waste," U.S. Department of Energy, Idaho Falls, ID, DE95009458, 1994, pp 1-1-29-6.

29. Feizollahi, F.; Quapp, W.J.; Hempill, H.G.; Groffie, F.J. "Integrated Thermal Treatment System Study - Phase 1 Results," U.S. Department of Energy, DE-AC07-761D01570, 1994, pp 1-167.

30. Gillis, P.J. Jr. "Radwaste Cost Savings and Mixed Waste Volume Reduction Achieved with $\mathrm{CO}_{2}$ Decontamination - Actual Utility History," Technology and Programs for Radioactive Waste Management and Environmental Restoration; Post, R.G., Ed.; 1994, pp 1647-1649.

31. Hanulik, J. "Decofor and Decoconcrete New Metal and Concrete Decontamination Processes for Decommissioning," 1994 International Symposium on Decontamination \& Decommissioning, U.S. Department of Energy.

32. Lomasney, H.L.; Yachmenev, V. "Electrokinetic Decontamination of Concrete," Proceedings of Opportunity '95: Environmental Technology Through Small Business; Kothari, V.P., Ed.; U.S. Department of Energy Morgantown Energy Technology Center, 1995, pp 190-191.

33. Moorthy, P.N.; Rao, U.R.K.; Venkateswaran, G. Gokhale, A.S.; Yuvaraju, B.; Vinaykumar, C.K.; Wagh, P.M.; Kansara, H.M. "Evaluation of Lomi and Citrate Formulations for the Decontamination of the Clean Up System Surfaces of Tarapur Atomic Power Station BWRS," 1994 International Symposium on Decontamination \& Decommissioning, U.S. Department of Energy.

34. Simmons, M. "Decontamination of Radioactive Concrete: A Permanent Solution That's RCRA Friendly," Radwaste Magazine 1994, 1, 25-29.

35. Tripp, J.L. "Criteria and Evaluation of Three Decontamination Techniques," U.S. Department of Energy Westinghouse Idaho Nuclear Company, Inc., Idaho Falls, ID, DEAC07841D12435, 1994, pp 1-11.

36. "Radiological Control Manual," Lawrence Berkeley Laboratory, CA, DE93 013925, 1993, pp 1-21.

37. Benda, G.A. "Commercial Experience in Treating U.S. Department of Energy Mixed Waste," in High Level Radioactive Waste and Spent Fuel Management, Vol. 2; Ahlstroem, P.E.; 
Chapman, P.E.; Kohout, R.; Mareke, J., Eds.; American Society of Mechanical Engineers: New York, 1993, pp 385-390.

38. Berg, H.P.; Debski, H.J. "Cost Analysis of German Waste Repositories," in High Level Radioactive Waste and Spent Fuel Management, Vol. 2; Ahlstroem, P.E.; Chapman, C.C.; Kohout, R.; Marek, J., Eds.; American Society of Mechanical Engineers: New York, 1993, pp 809-814.

39. Bonem, M.W.; Borah, R.E.; Rathke, S.E. "Extraction of Contaminants from Porous Surfaces - Case History," Meeting the Challenge - ER '93, Environmental Remediationt Conference, U.S. Department of Energy, 1993, pp 1009-1011.

40. Bossart, S.J.; Moore, J. "Innovative Technologies for Recycling Contaminated Concrete and Scrap Metal," Meeting the Challenge - ER '93, Environmental Remediation Conference, U.S. Department of Energy, 1993, pp 335-338.

41. Cannon, N.S.; Flesher, D.J. "Lasers for the Radioactive Decontamination of Concrete," Proceedings of the International Conference on Lasers and Applications; U.S. Department of Energy, Richland, WA, DE94003468 CT, 1993.

42. Christ, B.G.; Wehner, E.L. "Project Specific Selection of Decommissioning Techniques," in High Level Radioactive Waste and Spent Fuel Management; Ahlstroem, P.E.; Chapman, C.C.; Kohout, R.; Marek, J., Eds.; American Society of Mechanical Engineers: New York, 1993, pp 189-192.

43. Closs, J.W. "Decommissioning Experience: One-Piece Removal and Transport of a LWR Pressure Vessel and Internals," High Level Radioactive Waste and Spent Fuel Management; Ahlstroem, P.E.; Chapman, C.C.; Kohout, R.; Marek, J., Eds.; American Society of Mechanical Engineers: New York, 1993, pp 105-109.

44. Corleto, P.; Guidotti, M.; Petagna, E.; Ragazzo, G. "A Microwave System to Scarify Concrete Surfaces: Development and Testing," High Level Radioactive Waste and Spent Fuel Management; Ahlstroem, P.E.; Chapman, C.C.; Kohout, R.; Marek, J., Eds.; American Society of Mechanical Engineers: New York, 1993, pp 439-444.

45. Feizollahi, F.; Shropshire, D. "Waste Management Facilities Cost Information Report for Greater-Than-Class C and DOE Equivalent Special Case Waste," U.S. Department of Energy, Idaho Falls, ID, DE94010770, 1993, pp 1-144.

46. Foster, D. "U.S. DOE Researchers Demonstrate Use of Microwaves to Decontaminate Concrete,"D\&D Technologies 1993, 1, 15-16.

47. Fujiki, K.; Nakamura, H. "Current Studies on the Decommissioning Materials Recycling at Japan Atomic Energy Research Institute," High Level Radioactive Waste and Spent Fuel Management; Ahlstroem, P.E.; Chapman, C.C.; Kohout, R.; Marek, J., Eds.; American Society of Mechanical Engineers: New York, 1993, pp 321-327. 
48. Guthrie, W.S. "Foam Technology as a Decontamination/Waste Minimization Tool (U)," U.S. Department of Energy Westinghouse Idaho Nuclear Company, Inc., Idaho Falls, ID, 1993, pp 243-248.

49. Ishikura, T.; Miwa, T.; Onozawa, T.; Ohtsuka, H.; Ishigure, K. "Development of Decontamination Techniques for Decommissioning Commercial Nuclear Power Plants," High Level Radioactive Waste and Spent Fuel Management; Ahlstroem, P.E.; Chapman, C.C.; Kohout, R.; Marek, J., Eds.; American Society of Mechanical Engineers: New York, 1993, pp 295-300.

50. Johnson, S.V.; Mayberry, J.J. "Management Approaches for Environmental Restoration at the U.S. Department of Energy Weapons Complex, Savannah River Site: A Case Study," High Level Radioactive Waste and Spent Fuel Management; Ahlstroem, P.E.; Chapman, C.C.; Kohout, R.; Marek, J., Eds.; American Society of Mechanical Engineers: New York, 1993, pp 349-351.

51. Long, F.G.; Ward, R.D.; McNicholas, P.; Albers, R.W.; Zaccai, H.; Tsyplenkov, V. "Assessment and Comparison of Waste Management Costs for Nuclear and Fossil Energy Sources," High Level Radioactive Waste and Spent Fuel Management; Ahlstroem, P.E.; Chapman, C.C.; Kohout, R.; Marek, J., Eds.; American Society of Mechanical Engineers: New York, 1993, pp 815-823.

52. Majersky, D.; Solcanyi, M.; Prazska, M. "Recent Trends in the Area of the Decontamination of Nuclear Power Plants in the Slovak Republic and in the Czech Republic," High Level Radioactive Waste and Spent Fuel Management; Ahlstroem, P.E.; Chapman, C.C.; Kohout, R.; Marek, J., Eds.; American Society of Mechanical Engineers: New York, 1993, pp 301-306.

53. Mantega, F.; Sanson, F.; Garofalo, A.; Vitiello, T. "Garitta Project: An Example of Conditioning of Large Dimensions Irradiated Components," High Level Radioactive Waste and Spent Fuel Management; Ahlstroem, P.E.; Chapman, C.C.; Kohout, R.; Marek, J., Eds.; American Society of Mechanical Engineers: New York, 1993, pp 445-454.

54. Panciatici, G.; Belfiore, A.; Poggianti, M. "Attapulgite, A Decontaminating Medium, Research Tool in the Radioprotection Field," High Level Radioactive Waste and Spent Fuel Management; Ahlstroem, P.E.; Chapman, C.C.; Kohout, R.; Marek, J., Eds.; American Society of Mechanical Engineers: New York, 1993, pp 313-320.

55. Pang, H.M.; Edelson, M.C.; Demmer, R. "Metal Decontamination Using High Power Lasers," Meeting the Challenge - ER '93, Environmental Remediation Conference, U.S. Department of Energy, 1993, pp 999-1004.

56. Pickett, J.B.; England, J.L.; Martin, H.L. "Life Cycle Cost Analysis Changes Mixed Waste Treatment Program at the Savannah River Site (U),"U.S. Department of Energy Westinghouse Savannah River Company, Aiken, SC, Conf 9303105, 1993. 
57. Santiago, J.L.; Sanchez, M. "Decommissioning and Waste Disposal Methods for an Uranium Mill Facility in Spain," High Level Radioactive Waste and Spent Fuel Management; Ahlstroem, P.E.; Chapman, C.C.; Kohout, R.; Marek, J., Eds.; American Society of Mechanical Engineers: New York, 1993, pp 193-197.

58. Sebastian, R.L.; Beck, B.G. "Integrated Apparatus for Mapping and Characterizing the Chemical Composition of Surfaces," VA Nos. 5416321 and 437220, 1993.

59. Sleeman, R.C. "Update of Lessons Learned from Cleanup Projects at Oak Ridge," High Level Radioactive Waste and Spent Fuel Management; Ahlstroem, P.E.; Chapman, C.C.; Kohout, R.; Marek, J., Eds.; American Society of Mechanical Engineers: New York, 1993, pp 333-335.

60. Vovk, I.F.; Movchan, N.P.; Fedorenko, Y.G.; Shpigun, A.A .; Zlobenko, B.P. "Research on Cleanup of Buildings and Structures in Urban Areas of Ukraine Affected by the Accident at the Chernobyl NPP," High Level Radioactive Waste and Spent Fuel Management; Ahlstroem, P.E.; Chapman, C.C.; Kohout, R.; Marek, J., Eds.; American Society of Mechanical Engineers: New York, 1993, pp 225-227.

61. Wei, T.; Hsieh, J. "The Experiences of Using Ultrahigh-Pressure Waterjet to Decontaminate the Nuclear Facilities at Iner," High Level Radioactive Waste and Spent Fuel Management; Ahlstroem, P.E.; Chapman, C.C.; Kohout, R.; Marek, J., Eds.; American Society of Mechanical Engineers: New York, 1993, pp 433-437.

62. Yanagihara, S.; Itoh, S.; Shiraishi, K. "Systems Engineering for Decommissioning the Japan Power Demonstration Reactor (JPDR) - A Study on Characteristics of Decommissioning Waste," High Level Radioactive Waste and Spent Fuel Management; Ahlstroem, P.E.; Chapman, C.C.; Kohout, R.; Marek, J., Eds.; American Society of Mechanical Engineers: New York, 1993, pp 423-431.

63. Feizollahi, F.; Shropshire, D. "Waste Management Facilities Cost Information Estimating Data," U.S. Department of Energy, Idaho Falls, ID, DE95009462, 1992, 319 p.

64. Jennings, H.T. "Method of Decontaminating a Cementitious Surface," Warrington, GBX Nos. 5414196 and 9616632, 1992.

65. Schlueter, R.; Schafer, J.J. "Low-Level and Transuranic Waste Transportation, Disposal, and Facility Decommissioning Cost Sensitivity Analysis," U.S. Department of Energy Idaho National Engineering Laboratory, Idaho Falls, ID, EGG-WTD--10092, 1992, pp 1-23.

66. Angus, M.J.; Hunter, S.R.; Ketchen, J. "Classification of Contaminated and Neutron-Activated Concretes from Nuclear Facilities Prior to Their Decontamination or Decommissioning," 1990 , pp 229-234.

67. Bullard, C.W.; Weger, H.T. "LLRW Disposal: Economies of Scale and Waste-Type Segregation," Energy Systems and Policy 1990, 14, 227-236. 
68. Gugan, M.A.; Sanders, M.J.; Collett, K.F. "Wet Abrasive Particle Impact Cleaning as a Nuclear Decontamination Technique," Proceedings of the International Topical Meeting on Nuclear and Hazardous Waste Management Spectrum '90; American Nuclear Society, Inc., LaGrange, IL, 1990, pp 269-271.

69. Konzek, G.J.; Smith, R.I. "Technology, Safety and Costs of Decommissioning a Reference Boiling Water Reactor Power Station - Comparison of Two Decommissioning Cost Estimates Developed for the Same Commercial Nuclear Reactor Power Station," Pacific Northwest Laboratory, Richland, WA, NUREG/CR-0672, 1990, pp 1-59.

70. Zaccai, H. "Evaluation of Storage and Disposal Costs for Conditioned Radioactive Waste in Several European Countries," Commission of the European Communities, Luxembourg, EUR12871,1990 , pp 1-45.

71. "Nuclear Waste - DOE's Method for Assigning Defense Waste Disposal Costs Complies with NWPA," B-202377, 1989, pp 1-31.

72. "Analysis of the Total System Life Cycle Cost for the Civilian Radioactive Waste Management Program," U.S. Department of Energy Office of Civilian Radioactive Waste Management, Washington, DC, DOE/RW-0236, 1989, pp 1-1-9-7.

73. Bealby, J. "Optimisation of Treatment, Storage and Disposal Strategies for (Unconditioned and Conditioned) Radioactive Waste," U.S. Department of Energy, London, UK, DOE-RW89.063, 1989, pp 1-27.

74. Chang, S.Y.; Rivera, A.L. "Theory and Evidence of Economies of Scale in the Development of Waste Management Systems," Presented at the U.S. Department of Energy Model Conference, Oak Ridge, TN, Oct. 2-6, 1989, 8910193--2, pp 1-52.

75. Morillon, C.; Routier, J.F.; Pilot, G. "Thermal Techniques for Surface Concrete Decontamination," Decommissioning of Nuclear Installations, Proceedings of the 1989 International Conference; Elsevier Applied Science: Barking, UK, 1989, pp 553-563.

76. Pick, M.E. "PWR Oxide Characterization/Surface Finish Improvement and Development of Decontamination Processes for Gas and Water Cooled Reactors," Decontamination and Decommissioning of Nuclear Facilities - Results of a Coordinated Research Programme, Phase II: 1989-1993; IAEA: 1989, pp 185-192

77. Collins, H.E.; Leach, E.W. "TAM-D3: Boiling Water Reactor Recirculation Pipe Replacement: Radiological Challenges, Innovative Solutions, and Long-Term Plant Impact," Thirty-Second Annual Meeting of the Health Physics Society, 1987, 52, Supplement 1.

78. Distenfeld, C.H.; Brosey, B.H.; Babel, P.J. "TAM-D4: A Collimated Surface Monitor for Estimating Activity Absorbed in Concrete Walls," Thirty-Second Annual Meeting of the Health Physics Society, 1987, 52, Supplement 1. 
79. Yasunaka, H.; Shibamoto, M.; Sukegawa, T.; Yamate, T. Tanaka, M. "Microwave Decontaminator for Concrete Surface Decontamination in JPDR," Proceedings of the 1987 International Decommissioning Symposium; Tarcza, G.A.,Ed.; U.S. Department of Energy Westinghouse Hanford Company, Richland, WA, DE87012822, 1987, pp 109-116.

80. Elder, H.K. "Technology, Safety and Costs of Decommissioning Reference Nuclear Fuel Cycle Facilities," Pacific Northwest Laboratory, Richland, WA, NUREG/CR-4519, 1986, pp 1-22.

81. U.S. Accounting Office. "Nuclear Waste - Cost of DOE's Proposed Monitored Retrievable Storage Facility," B-202377, 1986, pp 1-31.

82. McIsaac, C.V.; Davis, C.M.; Horan, J.T.; Keefer, D.G. "Results of Surface Activity and Radiation Field Measurements Made During Surface Decontamination Experiments Conducted at TMI-2," Proceedings of the American Nuclear Society Meeting on Fission - Product Behavior and Source Term Research; Huebner, M.F., Ed.; U.S. Department of Energy, 1985, pp 1-17.

83. Pavelek, M.D. II; Carmel, P.G. "Volume Reduction of Contaminated Concrete Shield Slabs Through Surface Removal," Waste Management ' 85 - Waste Isolation in the U.S. Technical Programs and Public Education - Waste Policies and Programs, Low-Level Waste; Post, R.G.,Ed.; U.S. Department of Energy: 1985, pp 303-307.

84. Kuriyama, O.; Koyama, T.; Kikuchi, M. "Decontamination of Radioactive Metal Surfaces by Plasma Arc Gouging," Nuclear Technology 1983, 61, 93-99.

85. Galecki, G.; Vickers, G.W. "The Development of Ice-Blasting for Surface Cleaning," 6th International Symposium on Jet Cutting Technology, BHRA Fluid Engineering, Bedform, UK, 1982, pp 59-79.

86. Halter, J.M.; Sullivan, R.G.; Bevan, J.L. "Surface Concrete Decontamination Equipment Developed by Pacific Northwest Laboratory," U.S. Department of Energy Pacific Northwest Laboratory, Richland, WA, DEAC0676RL01830, 1982, pp 1-D.1.

87. McCoy, M.W.; Allen, R.P.; Fetrow, L.K.; Hazelton, R.F. "Vibratory Finishing for Decontamination - Pilot Scale Operation," The Treatment and Handling of Radioactive Wastes; Blasewitz, A.G.; Davis, J.M.; Smith, M.R., Eds.; Battelle Press \& Springer/Verlag: Columbus, OH, and New York, 1982, pp 109-113.

88. Kennedy, W.E. Jr.; Watson, E.C.; Murphy, D.W.; Harrer, B.J.; Harty, R.; Aldrich, J.M. "A Review of Removable Surface Contamination on Radioactive Materials Transportation Containers," Pacific Northwest Laboratory, Richland, WA, NUREG/CR-1858, 1981, pp $1.1-6.2$.

89. Cox, E.J.; Garde, R. "Decontamination of Concrete Surfaces at the Los Alamos Scientific Laboratory," 1980. 
90. Arrowsmith, H.W.; Allen, R.P. "New Decontamination Techniques for Exposure Reduction," U.S. Department of Energy Environmental Control Symposium, 1979, pp 183-206.

91. Clark, J.H.; Dippel, T. "Manual on Decontamination of Surfaces," Safety Series, International Atomic Agency, Vienna, Austria, 1079, pp 1-44.

92. Halter, J.M.; Sullivan, R.G. "Techniques for Removing Contaminated Concrete Surfaces," Environmental Decontamination 1979, 185-194.

93. Halter, J.M.; Sullivan, R.G. "Contaminated Concrete Surface Layer Removal," EY-76-C-061830; reprinted from Surface Contamination, Vol. 1; Mittal, K.L., Ed.; Plenum Publishing: New York, 1979, pp 443-455.

94. Kunze, S. "Waste-Compatible Cleansers for Elimination of Surface Contaminations," Kerntechnik 1979, 34, 147-150.

95. Barbier, M.M.; Chester, C.V. "Decontamination of Large Horizontal Concrete Surfaces Outdoors," U.S. Department of Energy, W-7405-eng-26, pp 1-26.

96. Benavides, E.; Fajardo, M. "Closed Electropolishing System for Decontamination of Underwater Surfaces/Development of Vibratory Decontamination with Abrasive Media," Decommissioning of Nuclear Facilities; Pflugrad, K.; Bisci, R.; Huber, B.; Skupinski, E., Eds.; Elsevier Applied Science: London \& New York, pp 598-603.

97. Carson, D.R.; Shagula, B.P.; Moran, J.B. "Human Factors Assessments of Environmental Technologies," U.S. Department of Energy Morgantown Energy Technology Center, 95MC32260, pp 1-11.

98. McKernan, M.L.; Schulmeister, A.R. "Surface Decontamination Utilizing Mechanical Vacuum Blasting Methods," U.S. Department of Energy, SSDP-0035.

99. Pang, H.M.; Lipert, R.J.; Hamock, Y.M.; Bayrakal, S.; Gaul, K.; Davis, B.; Baldwin, D.P.; Edelson, M.C. "Laser Decontamination - A New Strategy for Facility Decommissioning." 
M97005478

Report Number (14)DOE/MC/31388- = 5780

Subl. Date (11) $\quad-199710$

sponsor Code (18) DOE/EM, XF

JC Category (19) UC-2000, DOE/ER

DOE 